\title{
Preparation of dried kofta formula from small size shrimp meat
}

\author{
Mahmoud FSAK; Shahin MFSA and Badawy M Darwesh
}

Meat \& Fish Technol. Res. Dept., Food Technology Research Institute, Agricultural Research Center, Giza, Egypt

\section{ABSTRACT}

he purpose of this study was to utilize small size shrimp meat for new $T$ products characterize with high nutritional value and easy preparation, beside to added value for small size shrimp. Small size shrimp meat was and used three formulas, formulal ( $F 1=$ dried shrimp meat $45 \%$ dried potato $35 \%)$, formula2 $(F 2=$ dried shrimp meat $50 \%$ and dried potato $30 \%$ ) and formula3 (F3= dried shrimp meat 55\% and dried potato 25\%). Other ingredients were added to all formulas with the same percentage. The products were analysis for gross composition, cholesterol content, water holding capacity (WHC), plasticity, rehydration ratio, cooking loss, water activity, thiobarbituric acid (TBA), total volatile nitrogen (TVN) and sensory evaluation were analyzed. The obtained results showed that F1 was the highest content of moisture and carbohydrates followed by F2 and F3. While, F3 was the highest content of protein, fat and ash followed $F 2$ and $F 1$, respectively. $F 3$ was the highest level of cholesterol followed by $F 2$ and F1, where recorded 45.125, 40.61 and 29.81 (mg/ 100g), respectively. All formulas F1, F2 and F3 were accepted for TBA and TVN. F3 was the best value of WHC, plasticity, cooking loss, rehydration ratio, water activity and total bacteria count (as quality properties) followed by F2 and F1. All samples were accepted by sensory evaluation. Where the results showed that the formula F3 was the highest significantly in score of taste and odor, followed by F2 and F1.Meanwhile, non significant differences of Sensory evaluation score of color, texture and overall acceptability between all formulas (F3, F2 and F1).

Key wards: dried meat, dried shrimp meat, dried kofta and shrimp meat kofta. 


\section{Introduction}

The modern technology in different fields gives chance for the meat processors to produce new products in different shapes, easily handled, stored and rapidly used .The need for meat products have many tasks includes new flavor, preservation and of low calories. The quality of raw material as well as the additives used in the final products is very important for public health (Pearson and Gillette, 1996 and Edris et al, 2012).

The shrimp is excellent sources of high quality proteins which are superior to those in meat and poultry. Biochemical assays and nutrients play a vital role in physical growth, development, maintenance of normal body function of physical activity and health, also it is excellent sources essential High-Unsaturated Fatty Acids (HUFA) such as eicosapentaenoic (20: 5n3, EPA) and docosahexaenoic (22: 6n3, DHA) acids (Feliz et al., 2002; Yanar and Celik, 2006). Besides, it is a good source of minerals and vitamins such as calcium, iron, zinc, copper, vitamin $\mathrm{B}_{12}$ and essential amino acids and shrimp is one of the most popular species as it is a part of almost every nation's traditional meal rich in protein and minerals (Dong, 2001; Yanar and Celik , 2005; Yanar and Celik, 2006).

Shrimps and shrimp products are one of the most economically important products. To increase the variety of shrimp products, value added products should be considered. However, the use of small shrimps or broken shrimp meat for new products is still limited. The Ready-to eat meat products are a high risk food group. Minced meat undergo oxidative changes and develop rancidity more quickly than intact muscle since grinding exposes more of the muscle surface to air and microbial contamination (Mitsumoto et al., 2005).

Dry-cured meat products constitute one of the most representative traditional foods that have been produced and consumed throughout history by a diversity of cultures in different areas of the world. 
These meat products, which have a wide variety of flavors and textures, represent an important part of local economies, particular cultures and gastronomic heritages. Dried meat products are stable at room temperature and are produced in nearly every country in the world, especially in developing countries where refrigeration is limited, such products use low cost source of energy for drying. These products are interest since they do not require refrigeration during marketing and storage and no noticeable changes in protein and fat content was observed during storage (Change, et al., 1996) and (Talib, et al., 2006). The development of new food products, it's through the discovery of new food products characterized by preparation speed and long shelf life. Today, there is an important trend to enrich our sensory perceptions and many consumers and meat industries around the world are getting more and more interested in dry-cured meat products (Fidel, 2006).
Technological

developments in meat processing, preservation and handling have give consumers a much greater choice over the foods they can buy. Consequently, consumers have become more selective and more considered about the quality of the product, which became a more significant factor in marketing meat products (Eman, 2009).

The goal of this study is prepare dried kofta from dried small size shrimp meat as a new product of small shrimp meat with high nutrition value and healthy and value added to small size shrimp. Characterized was the length of preservation, ease in handling, speed in preparing and processing. The study was on the composition and nutrient value of these product, chemical and physical quality attributes and the sensory properties.

\section{Materials \& Methods}

Materials 
Small size shrimp (Penaeus semisulactus) was obtained local market at Giza, Egypt.

\section{Methods}

Drying the small size shrimp meat

Small size Shrimp were good washed and peeled for extract the meat only and minced all the extract meat together,the minced extract meat were placed as a thin layer on drying trays, the trays were placed in oven dryer(provided with a fan and thermostatically controlled electrical heater) and dried at $45{ }^{0} \mathrm{C}$ for $48 \mathrm{~h}$ then left it to cool at room temperature, the dried meat shrimp were ground to fine powder and packed in polyethylene bags Galhom (2002).

\section{Drying the potato}

Potato were peeled, good washed ,cut as chips shape then soaked for 30 minute in 1 $\%$ citric acid solution, after that the potato was drained on sieve and left it for 15 minute, then placed it as thin layer on drying trays ,then the drying trays were placed in oven dryer (provided with a fan and thermostatically controlled electrical heater ) and dried at 45 ${ }^{0} \mathrm{C}$ for $10 \mathrm{~h}$ then left it to cool at room temperature, then ground to fine powder and packed in polyethylene bags Galhom (2002).

\section{Drying the onion}

Fresh onion were peeled, washed, cut and soaked for 10 minute in $1 \%$ citric acid solution, then placed it as thin layer on drying trays, then the drying trays were placed in oven dryer (provided with a fan and thermostatically controlled electrical heater) and dried at 45 ${ }^{0} \mathrm{C}$ for $10 \mathrm{~h}$ then left it to cool at room temperature, then ground to fine powder and packed in polyethylene bags.

Different formulas of dried kofta from small size shrimp meat

Dried shrimp meat, dried potato and dried onion and the rest ingredients (spices and salt) were mixed together as table (1) and packed in polyethylene bags until use. 
Preparation of the dried kofta from small size shrimp meat

To prepare the dried kofta from small size shrimp for consumption, $100 \mathrm{~g}$ from each blend as table (1) was mixed with $100 \mathrm{ml}$ of water and one whipped whole egg and homogenized. Then formed into finger shape and coated with fine rusk then fried in edible oil.

\section{Chemical analyses:}

Chemical composition (moisture, protein, fat and ash) was determined according to A.O.A.C. (2000). Total carbohydrate was calculated by the difference as follows: Total carbohydrate $=100-$ (moisture + protein + fat + ash). Cholesterol was determinate according to the methods of Katsanidis and Addis, (1999). Caloric value determinate (Kcal) were calculated using method of Watt and Mersil (1975).

Chemical quality attributes:

Total volatile nitrogen (TVN) was determined according to the method published by Winton and
Winton (1958). the $\mathrm{pH}$ value was determined according to Aitken, et al., (1962). Thiobarbituric acid (TBA) value was determined as described by Egan et al., (1981).

\section{Physical properties:}

Water Holding Capacity (WHC) and plasticity were measured during storage period according to the filter press method of Soloviev (1966). The cooking loss was determined according to Mahmoud (2008 ).The water activity of the dried samples mixtures were measured using Rotronic Hygrolab $3 \mathrm{CH}-$ 8303, Switzerland as mentioned by Cadden (1988). Rehydration ratio was performed according to the methods of Krokida and Marinos-Kouris (2003).

\section{Sensory evaluation:}

Sensory evaluation of kofta from small size shrimp meat was carried out according to Watts et al. (1989).

Statistical analysis:

Data were subjected to Analysis of Variance (ANOVA). Means comparison was 
performed using Duncan's test at the $5 \%$ level of probability as reported by Snedecor and Cochran (1994).

\section{Results \& discussion}

The results presented in table (2) pointed the chemical composition of small size shrimp meat before and after drying, these results indicated that as is typical of most sea foods, the fresh shrimp was $78.35 \%$ moisture. This result compares well with $80.5 \%$ and $77.2 \%$ reported in earlier studies for black tiger shrimp and white shrimp, respectively ( Sriket et al,2007 and Akonor et al,2016). After drying, moisture was reduced to about $7.85 \%$, which is less than the specified moisture for dried shrimps (Tapaneyasin et al, 2005). Low moisture content in dried shrimp meat is encouraged to safeguard the product from microbial attack and enzymatic action and therefore prevent spoilage.

According to (Egyptian

\section{Organization Standardization} E.O.S, 1993) dried shrimp meat should not be containing moisture more than $8.0 \%$. It is clear that this level not exceeded this amount in this study. Protein was the second most abundant component of the shrimp meat, and this made up about $17.85 \%$ of fresh meat (Table 2). After drying, protein was increased to about $70.65 \%$. The high protein content of dried shrimp meat makes it a good source of amino acids for human diets as reported by Akonor et al, (2016). Fat content of fresh shrimp meat was $1.74 \%$ as table (2), this near of the results obtained by Takama et al, (1999) and Sriket et al, (2007). After drying fat content increased to $11.20 \%$, this may be due to the loss of moisture content by evaporation and concentrated other compounds. Ash represents the total mineral content in food and is essential in maintaining several bodily functions. Shrimp meat was found to contain appreciable amounts of ash, in the present study, ash content of fresh shrimp meat was 1.82 increased to $9.30 \%$ in dried shrimp meat after drying this may be due to moisture loss and concentration of chemical components. This 
makes shrimp meat a good source of minerals in the diet.

The data in table (3) showed chemical composition of the processed formulas of dried kofta from dried small size shrimp meat. There was some variation in moisture, protein, ash, fat and carbohydrate content, this may be due to the variation in type and level of dried small size shrimp meat and potato powder used. F3 has The highest level of protein contain $(19.18 \%)$, fat $(7.22 \%)$ and ash $(5.95 \%)$ and the lowest level of moisture and carbohydrate content followed by $\mathrm{F} 2$ and $\mathrm{F} 1$ respectively this may be due to F3 had the highest level of dried small size shrimp meat $(55 \%)$ followed by F2 (50\%) and F1 (45\%), respectively. Similar results are reported by El-Sherif and Ibrahim, (2012), where found that kofta from carp meat contained moisture (58.64\%), protein $(13.25 \%)$, fat $(8.85 \%)$, ash $(3.30 \%)$ and carbohydrate (15.96\%).Similar results are reported by Mostafa $\boldsymbol{e t} \boldsymbol{a l}$. (2002), Levent et al. (2011).
Results presented in table (3) showed that F3 recorded the highest level of caloric value followed by $\mathrm{F} 2$ and F1 respectively; this may be due to level of dried small size shrimp meat and potato powder used as table (1). Where, F3 had the highest content of protein and fat and the lowest content of carbohydrate followed by F2 and F1, respectively.

Regarding to table (3) showed the cholesterol content of the processed formulas of dried kofta from dried small size shrimp meat, it could be concluded that F3 was the highest level of cholesterol content followed by F2 and F1, where recorded 45.125, 40.61 and $34.81 \quad(\mathrm{mg} / \mathrm{100g})$ respectively. This results confirmed with the obtained results by Shahin et al( 2016), where found that the cholesterol content in different formulas $\mathrm{o}$ fish burger from small size shrimp and carp fish meat ranged 18.52 to 43.39 (mg/ $100 \mathrm{~g}$ ). This may be due to the cholesterol content of fresh shrimp meat was higher (173 $\mathrm{mg} / 100 \mathrm{~g}$ ), while the cholesterol 
absent in potato according to Syama et al. (2013).

Cholesterol

level increased with increasing the Add proportion of dried small size shrimp meat and reducing the Add proportion of potato powder in formulas of the kofta, so F1 was the lowest level of cholesterol followed by F2 and F3 respectively. Fresh and clean shrimps can be served either cooked or uncooked with sauce. From a nutritional standpoint, shrimps are high in protein, low in saturated fat and calories, and have a neutral flavor. Due to these characteristics, shrimps form a natural additive in salads, pastas, curry, soups and stir-fried dishes. Shrimps have also been identified as a rich source of vitamin B12, selenium, $\omega-3$ highly unsaturated fatty acids (HUFA) and natural antioxidant (Feliz et al., 2002 and Venugopal., 2008). Despite the several nutritional parameters of shrimp based on which it can be considered as a healthy food, there is reluctance among dieticians and health professionals as well as consumers because of its relatively higher cholesterol. A clinical study showed that moderate shrimp consumption in normolipidemic subjects will not adversely affect the overall lipoprotein profile and can be included in 'heart healthy' nutritional guidelines (Syama $\boldsymbol{e t}$ al., 2013). Therefore, this work was conducted to production new shrimp products included on nutritive value of shrimp meat and reducing the risk of consumption of level cholesterol in shrimp meat.

The data in table (4) indicated that F3 contained the highest level of TV N (32.7 $\mathrm{mg} / 100 \mathrm{mg}$ ) followed by F2 and F1 that gave $(32.15 \mathrm{mg} / 100 \mathrm{mg})$ and (30.25 mg/100mg) , respectively, this may be due to protein content was higher in F3 compared with F2 and F1, respectively as indicated in table (3), because there are direct relationship between protein content and TVN, during drying period, microbial and enzyme active led to disintegration protein components so with increasing protein content in sample increase level TVN. Similar results are reported by 
Galhom (2002), where, found that TVN of kofta prepared from dried bolti and keshr bayed fish was 40.4 and $40.1 \mathrm{mg} / 100 \mathrm{mg}$, respectively.

\section{According to E.O.S.} (1993), TVN level in dried shrimp should not exceed be more than $65 \mathrm{mg} / 100 \mathrm{mg}$ (w.w.). Generally, TVN levels in all formulas were lower than the allowable limit.

At the same table (4), the data showed that $\mathrm{F} 3$ recorded the highest value of $\mathrm{pH}$ followed by $\mathrm{F} 2$ and F1. This is confirmed by the higher TVN content of F3 than formulas F2 and F1 as there is direct relationship between TVN content and $\mathrm{pH}$ value (Sanchez- Alouso et al., 2007).

From data presented in table (4), it could be noticed F1 recorded the lowest value of TBA followed by F2 and F3. This is confirmed by the higher Fat content of F3 than formulas $\mathrm{F} 2$ and $\mathrm{F} 1$ as there is direct relationship between TBA content and Fat content as table ( 2). During drying period, microbial and enzyme active oxidation processing led to disintegration fat, so may be with increasing fat content in sample increase level TBA.

From results presented in table (5) showed the Water Holding capacity after processing the different formulas from dried kofta shrimp meat. It could be noticed that, F1 samples recorded the highest area of Water Holding capacity (the worst as quality attributes) and followed by formula F2 and F3, respectively, so maybe there is positive relationship between water holding capacity and protein content (table 2), it is known that protein works as a binder, where there is positive relationship between protein and water holding capacity. This confirmed with the obtained results by Mahmoud (2008) and Shahin et al (2016).

From the obtained data presented in the same Table (5) showed plasticity after processing the different formulas from dried kofta shrimp meat, plasticity (as indicator for texture) was completely affected by the level of WHC, therefore, plasticity of F1 (less WHC as quality 
attributes) was lower than that of f2 and f3, respectively.

From the obtained data presented in Table (5) showed cooking loss the after processing and cooking different formulas from dried kofta shrimp meat, it could be noticed that, cooking loss of F1 was higher (as number, but the worst as quality attributes) followed by formula $\mathrm{F} 2$ and F3, respectively, this was also in accordance reverse with the levels of WHC, indicating that the better WHC (as quality attributes) the lower the cooking loss was found.

Rehydration refers to the process of moistening a dried product and is an indicator of quality criterion in most dried foods. It is an indicator of cellular and structural disintegration that occurs during dehydration (Rastog et al, 2000). The rehydration capacity was used as a quality characteristic of the dried product expresses in the rehydration rate (Velić et al., 2004). The rehydration properties, rehydration rate, and rehydration capacity are important characteristics of many products, related to their later preparation for consumption (Jokić et al., 2009). When the dried foods are reconstituted, it must show acceptable textural, visual, and sensory characteristics, while the rehydration time is minimized (García-Pascual et al., 2006). The results in our study pointed that F3 had the highest value of Rehydration ratio when compared with F2 and F1. This may be due to F3 had the lowest content of moisture compared with F2 and F1 as table (3). This results similar with earlier studies for Taiwo et al, (2002) and Krokida and MarinosKouris, (2003) and Akonor at al,(2016), where found that rehydration ratio of dried shrimp meat by different drying methods (air-oven dryer and a tunnel solar dryer) ranged between 1 to1.95.

Water activity is one of the most important tests for dried foods due to its relation to the shelf life of these dried products, which affects the activity of enzymes and microorganisms, Where the water activity required for 
growth most bacteria, fungi and yeasts ranged from 0.61 to 0.97 (Anthony and Fontana, 2008). The data in table (5) showed water activity of different formulas of dried kofta from small size shrimp ,the obtained data indicated that the water activity for all formulas were $0.465,0.483$ and 0.458 to $\mathrm{F} 1, \mathrm{~F} 2$ and F1,respectevily, it's clear that inducted that different formulas of dried kofta is sufficiently dried to minimize microbial growth.

From the same table (5) total bacteria count of the processed formulas were $\mathrm{F} 1$ relatively higher $\left(8 \times 10^{3} \mathrm{cfu} / \mathrm{g}\right)$ than F2 and F3 which gave $5 \times 10^{3}$ and $2 \times 10^{3}(\mathrm{cfu} / \mathrm{g})$, respectively. This may be due to F1 was higher of moisture content and water activity when compared with F2 and F3 ,respectively, this allowed to slightly faster bacterial growth in F1 compared with F2 and F3, respectively.

\section{According to E.O.S.} (1993), Total bacteria count (TBC) in dried shrimp meat should not exceed be more than $1 \times 10^{6}(\mathrm{cfu} / \mathrm{g})$. Generally, it's clear that Total bacteria count (TBC) in all formulas were lower than the allowable limit.

The average of total score of Sensory evaluation for (color, taste, odor, texture and overall acceptability) was evaluated by the panelists in Table (6). Sensory evaluation was after processing and cooking different formulas from dried kofta shrimp meat. The results showed that the formula (F3) was the highest significantly in score of taste and odor, where gave7.85 and 7.90 as average of total score for taste and odor, respectively, followed by $\mathrm{F} 2$ and F1which recorded (7.70 and 7.75) and (7.40 and 7.45 ) as total score, respectively Meanwhile, non significant differences of Sensory evaluation score of color, texture and overall acceptability between all formulas (F3, F2 and F1).

\section{Conclusion:}

The results indicated that all processed formulas of dried kofta from dried small size shrimp meat were accepted for TVN, TBA, total bacteria count, color, taste, aroma, texture and 
overall acceptability and reducing the risk of consumption of high level cholesterol in shrimp meat if it was consumed alone. it can be utilize from small size shrimp meat to produce dried kofta as a new product characterized with high nutritive value and healthy and value added to small size shrimp .This product Characterized by the length of preservation, ease in handling, speed in preparing and processing.

\section{REFERENCE}

Aitken A; Casey JC; Penny IF and Voyle CA (1962):

Effect of drying
temperature accelerated freeze of prok. J. Sci. of Food Agric, 13,439-448.

Akonor PT; Ofori1 H; Dziedzoave1 NT and Kortei N K (2016):
Drying
Characteristics and Physical and Nutritional Properties of Shrimp Meat as Affected by Different Traditional Drying Techniques.

International Journal of Food Science, Article ID 7879097, 5 pages.

\section{Anthony $J$ and Fontana Jr (2008): \\ Minimum Water Activity \\ Limits for Growth of \\ Microorganisms. Online ISBN: 9780470376454.}

AOAC (2000);

Association of Official Analytical Chemists Official Methods of Analysis.17th ed., Washington, USA.

Change SF; Huang TC and Pearson AM (1996):

Control of the dehydration process in production of intermediate- moisture meats products: a Review.1: Advc. Food Nutr. Res., 39, 71- 161.

Cadden AM (1988):

Moisture Sorption Characteristics of Several Food Fibers. Journal of Food Science, 53, 11501155. 
Dong FM (2001):

The Nutritional Value of Shellfish. Grant No. NA76RG0119, Project A/PC-5, USA: National Oceanic and Atmospheric Administration to Washington Sea Grant, University of Washington.

Edris AM; Faten SH; Hassan MAa $E$ M and Shaimaa MN (2012):

Studies On Chemical Composition And Quality Indices Of Beef Kofta And Sausage. Benha Veterinary Medical Journal, Vol. 23, No. , 116- 122.

Egan H; Kirk RS and Sawyer R (1981):

Pearson`s Chemical Analysis of Foods.8th ed. Churchill Livingstone. Longman Group Limited U.K.

\section{Egyptian Organization}

Standardization E. O. S. (1993):

Dried shrimp. E.S: $1993-$ 549
Eman MAE (2009):

Chemical and nutritional criteria of some camel products. Ph.D. Thesis. Fac. Vet. Med., Benha Univ.

El-Sherif S A and Ibrahim SM (2012):

Nutritive Value Of Some Fast Products Made From Silver Carp Fish, In Lake Wadi El-Rayan, ElFayoum, Egypt. J. Food and Dairy Sci., Mansoura Univ., Vol. 3 (12): 735 743.

Feliz GLA; Gatlin MD; Lawrence $L A$ and Velazquez PM (2002):

Effect of dietary phospholipid on essential fatty acid requirements and tissue lipid composition of Litopenaeus vannamei juveniles, Aquaculture, 207: 151-167.

Fidel T (2006):

Dry-cured meat products, Ph. D. Institute of Agrochemistry and Food Technology (CSIC) PO 
BOX 73, 46100 Burjassot (Valencia), SPAIN.

Galhom GFAA (2002):

Chemical and technological studies on some dried fish products.M. Sc. Thesis, fac. of agric., Cairo University.

García-Pascual P; Sanjuán N; Melis R and Mulet A (2006):

Morchella esculenta (Morel) Rehydration Process Modeling. Journal of Food Engineering, 72, 346-353.

Jokić S; Mujić I; Martinov M; Velić D; Bilić $M$ and Lukinac J(2009):

Influence of Drying Procedure on Colour and Rehydration Characteristic of Wild Asparagus. Czech Journal of Food Science, 27, 171-177.

Katsanidis E and Addis PB (1999):

"Novel HPLC analysis of tocopherols, tocotrienols, and cholesterol in tissue," Free Radical Biology and
Medicine,

27(11-12): 1137-1140.

Krokida MK and MarinosKouris D (2003):

Rehydration Kinetics of Dehydrated Products. Journal of Food Engineering, 57, 1-7.

Levent İ; Şengül B and Ali G (2011):

Production of fish fingers from sand smelt (Atherina boyeri, RISSO 1810) and determination of quality changes. African Journal of Biotechnology Vol. 10 (21), PP. 4464 - 4469.

Mahmoud FSK (2008):

Studies on some marine foods. Ph. D. Thesis, Faculty of Agriculture, Minufiya Univ. Egypt.

\section{Mitsumoto M; O'Grady MN;} Kerry JP and Buckley DJ (2005):

Addition of tea catechins and vitamin $\mathrm{C}$ on sensory evaluation, color and lipid stability during chilled storage in cooked or raw 
beef and chicken patties. Meat Sci., 69, 773-779.

Mostafa M M; Abo-Taleb M and Ibrahim SM (2002):

Evaluation of Patties Manufactured from Tuna and Catfish. Annals of Agric. Sc., Moshtohor, Vol. 40 (3); 1595-1606, (2002).

Pearson AM and Gillette TA (1996):

Processed meats. 3rd Ed New York Albany, Bonn, Boston, London.

Rastog NK; Angersbach A; Niranjan $K$ and Knorr $D$ (2000):

"Rehydration kinetics of high-pressure pre-treated and osmotically dehydrated pineapple," Journal of Food Science, vol. 65, no. 5, pp. 838841.

Sanchez-Alonso I; Jimenez EA; Sura F and Borderias AJ (2007):

Antioxidant protection of white grapa pomace on restructured fish products during frozen storage. Food Sci. and Technolo., 41(1): 1-9.

Shahin MFSA; Mahmoud FSAK and Sanaa A H (2016):

Production of New Burger from Small Size Shrimp and Carp Fish Meat. Current Science International 5(2): 223230.

\section{Snedecor GW and Cochran WG (1994):}

Statistical Methods. 8th Edn., East-West Press Pvt. Ltd., New Delhi, India, pp: 313.

Soloviev VE (1966):

Meat Aging. Food Industry. Pub., Moscow, pp: 53-81.

Syama DJ; Ponniah AG; Imran Khan H; Madhu Babu EP; Ambasankar $K$ and Kumarguru Vasagam KP(2013):

Shrimps - a nutritional perspective. Current 
Science, 104(11): 10,14871491

Sriket P; Benjakul S; Visessanguan $W$ and Kijroongrojana K(2007):

"Comparative studies on chemical composition and thermal properties of black tiger shrimp (Penaeus monodon) and white shrimp (Penaeus vannamei) meats," Food Chemistry, vol. 103, no. 4, pp. 1199-1207.

Taiwo K; Angersbach A and Knorr D( 2002):

"Rehydration studies on pretreated and osmotically dehydrated apple slices," Journal of Food Science, vol. 67, no. 2, pp. 842847.

\section{Takama K; Suzuki T; Yoshida} K; Arai H and Mitsui T(1999): "Phosphatidylcholine levels and their fatty acid compositions in teleost tissues and squid muscle," Comparative Biochemistry and Physiology B.
Talib M A; Alian AM and Salama N A (2006):

Effect of dehydration and preservatives on physicochemical properties of sun-dried and freeze-dried buffalo meat. J. Agric. Sci. Mansoura Univ., 31, 6959-6965.

\section{Tapaneyasin R; Devahastin S} and Tansakul A( 2005):

"Drying methods and quality of shrimp dried in a jet-spouted bed dryer," Journal of Food Process Engineering, vol. 28, no. 1, pp. 35-52.

\section{Yanar Y; Büyükçapar H; Yana $M$ and Göçer M (2006): \\ Effects of carotenoids from red pepper and marigold flower on pigmentation: Sensory properties and fatty acid composition of rainbow trout. Food Chem., 100: 326-330.}

\section{Yanar Y and Celik M (2005):}

Seasonal amino acid profiles and mineral contents of green tiger 
shrimp (Penaeus

semisulcatus De Haan, 1844) and speckled shrimp (Metapenaeus monocrecos Fabricus, (1789) from the Eastern Mediterranean Sea. Food Chemistry, 94:33-36.

\section{Venugopal V (2008):}

Marine Products for Healthcare: Functional and Bioactive Nutraceutical Compounds from the Ocean, CRCPress, London, UK.

Velić D; Planinić Tomas S and Bilić M (2004):

Influence of Airflow Velocity on Kinetics of Convection Apple Drying. Journal of Food Engineering, 64, 97-102. book No

(8) and Washington USA.

Watts BM; Yamaki GL; Jeffery LE and Elias LG (1989):

Basic Sensory Methods for Food Evaluation. 1st Edn., The International Development Research Center Pub., Ottawa, Canada.

Winton AL and Winton RB (1958):

Oxide distillation volumetric method for the determination of total volatile nitrogen. The Analysis of Foods P.848.John, Wiley and Sons, New York. Chapmann and Hall. London.

\section{Watt BK and Mersil AL} (1975):

Composition of foods raw processed, prepared. Rev. USDA Agriculture hand 
Table (1): Composition of different formulas from dried kofta from small size shrimp

\begin{tabular}{|c|c|c|c|}
\hline Ingredients \% & F1 & F2 & F3 \\
\hline Dried shrimp meat & 45 & 50 & 55 \\
\hline Dried potato & 35 & 30 & 25 \\
\hline Dried onion & 10 & 10 & 10 \\
\hline Black pepper & 1 & 1 & 1 \\
\hline Red pepper & 0.6 & 0.6 & 0.6 \\
\hline Cinnamon & 1.0 & 1.0 & 1.0 \\
\hline Cumin & 2.1 & 2.1 & 2.1 \\
\hline Cardamom & 0.3 & 0.3 & 0.3 \\
\hline Nutmeg & 0.3 & 0.3 & 0.3 \\
\hline Peppermint & 0.3 & 0.3 & 0.3 \\
\hline Clove & 0.5 & 0.5 & 0.5 \\
\hline Cubibe & 0.6 & 0.6 & 0.6 \\
\hline Curry & 0.3 & 0.3 & 0.3 \\
\hline Salt & 3.0 & 3.0 & 3.0 \\
\hline
\end{tabular}

Table (2): Chemical composition of fresh and dried small size shrimp meat ( $\%$ on wet weight basis)

\begin{tabular}{|c|c|c|}
\hline $\begin{array}{c}\text { Type of shrimp } \\
\text { item }\end{array}$ & $\begin{array}{c}\text { Fresh shrimp } \\
\text { meat }\end{array}$ & $\begin{array}{c}\text { Dried } \\
\text { shrimp meat }\end{array}$ \\
\hline Moisture content \% & 78.35 & 7.85 \\
\hline Protein content \% & 17.85 & 70.65 \\
\hline Fat content \% & 1.88 & 11.20 \\
\hline Ash content & 1.92 & 9.30 \\
\hline
\end{tabular}


Table (3): Chemical composition of the processed formulas from dried kofta shrimp meat (\% on wet weight basis)

\begin{tabular}{|l|c|c|c|}
\hline \multicolumn{1}{|c|}{ Formulas } & F1 & F2 & F3 \\
\hline Item & & & \\
\hline Protein \% & 53.70 & 52.92 & 52.39 \\
\hline Fat \% & 18.12 & 18.62 & 19.18 \\
\hline Ash \% & 6.12 & 6.64 & 7.22 \\
\hline Carbohydrates \% & 16.91 & 16.31 & 15.26 \\
\hline Caloric value (kcal /100g) & 195.20 & 199.48 & 202.74 \\
\hline $\begin{array}{l}\text { Cholesterol content (mg/ } \\
\text { 100g) }\end{array}$ & 34.81 & 40.61 & 45.13 \\
\hline
\end{tabular}

Table (4): Chemical quality attributes of the processed formulas from dried kofta shrimp meat

\begin{tabular}{|c|c|c|c|}
\hline $\begin{array}{ll} & \text { Formulas } \\
\text { Item } & \end{array}$ & F1 & F2 & F3 \\
\hline TVN (mg/100mg) & 30.25 & 32.15 & 32.70 \\
\hline pH & 8.1 & 8.13 & 8.15 \\
\hline $\begin{array}{l}\text { TBA (mg } \\
\text { malonaldehyde/kg) }\end{array}$ & 0.42 & 0.48 & 0.55 \\
\hline
\end{tabular}

$T V N=$ Total volatile nitrogen .

TBA=Thiobarbituric acid. 
Table (5): Physical properties of the processed formulas from dried kofta shrimp meat.

\begin{tabular}{|c|c|c|c|}
\hline Formulas & F1 & F2 & F3 \\
\hline $\begin{array}{c}\text { Water holding capacity }\left(\mathrm{Cm}^{2} / 0.3\right. \\
\text { gm })\end{array}$ & 1.65 & 1.54 & 1.35 \\
\hline Plasticity $\left(\mathrm{Cm}^{2} / 0.3 \mathrm{gm}\right)$ & 2.9 & 3.1 & 3.15 \\
\hline Cooking loss \% & 14.55 & 13.35 & 12.75 \\
\hline Rehydration ratio & 1.55 & 1.78 & 1.93 \\
\hline Water activity & 0.495 & 0.483 & 0.458 \\
\hline Total bacteria count TBC $(\mathrm{cfu} / \mathrm{g})$ & $8 \times 10^{3}$ & $5 \times 10^{3}$ & $2 \times 10^{3}$ \\
\hline
\end{tabular}

Table (6): Sensory evaluation of the processed formulas from dried kofta shrimp meat

\begin{tabular}{|l|l|l|l|l|}
\hline & F1 & F2 & F3 & LSD \\
\hline Color & $8.0^{\mathrm{a}} \pm 0.25$ & $8.0^{\mathrm{a}} \pm 0.20$ & $8.0^{\mathrm{a}} \pm 0.20$ & 0.425 \\
\hline Taste & $7.4^{\mathrm{b}} \pm 0.20$ & $7.70^{\mathrm{a} b} \pm 0.20$ & $7.85^{\mathrm{a}} \pm 0.20$ & 0.3995 \\
\hline Odor & $7.45^{\mathrm{b}} \pm 0.15$ & $7.75^{\mathrm{ab}} \pm 0.18$ & $7.9^{\mathrm{a}} \pm 0.20$ & 0.03553 \\
\hline Texture & $7.40^{\mathrm{a}} \pm 0.18$ & $7.45^{\mathrm{a}} \pm 0.15$ & $7.55^{\mathrm{a}} \pm 0.15$ & 0.03209 \\
\hline $\begin{array}{l}\text { Overall } \\
\text { acceptability }\end{array}$ & $7.587^{\mathrm{a}} \pm 0.21$ & $7.725^{\mathrm{a}} \pm 0.19$ & $7.525^{\mathrm{a}} \pm 0.19$ & 0.3937 \\
\hline
\end{tabular}

The letter $a, b, c, d$, e and $f$ means with in a row followed by the same letter are nonsignificantly different $(P \leq 0.05)$. 


\section{إعداد خلطاث كفتة مجفةة من لحم الجمبرى صغير الإ}

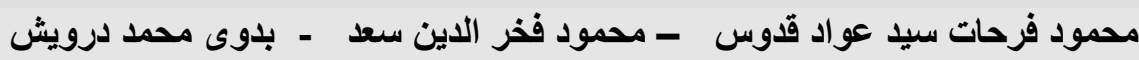

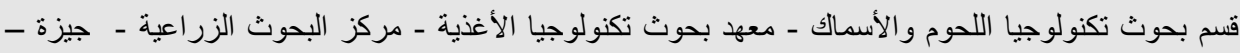
مصر

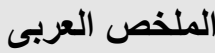

تهذف هذه الدراسة الى الاستفادة من لحم الجمبري صنير الحجم فى إنتاج منتجات جديدة

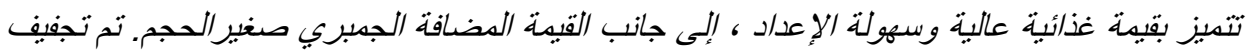

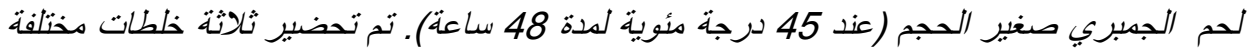

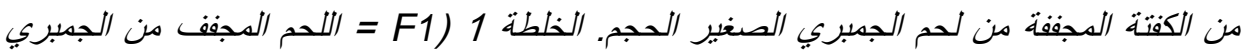

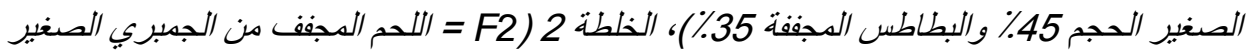

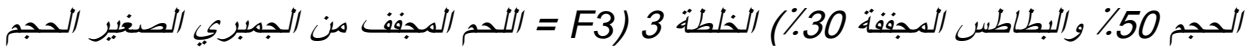

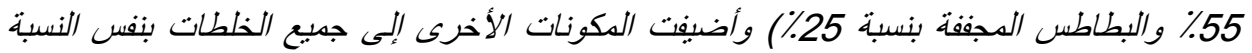

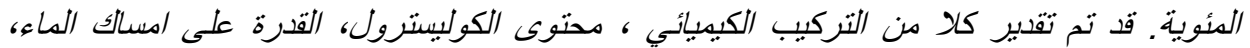

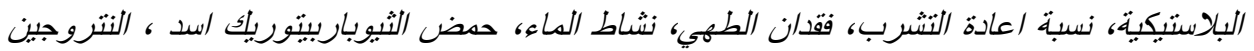

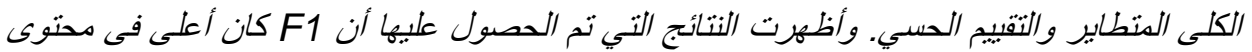

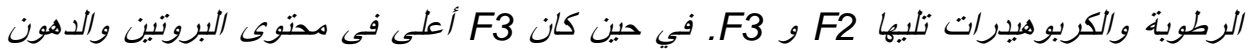

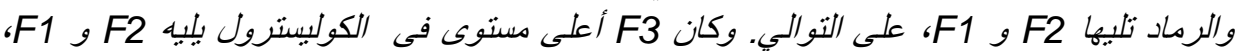

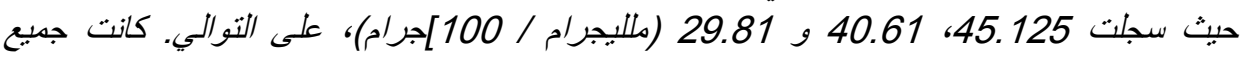

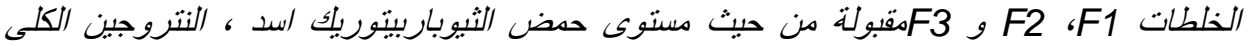

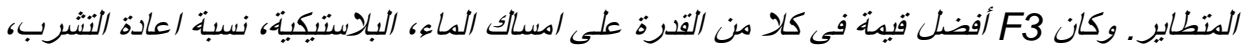

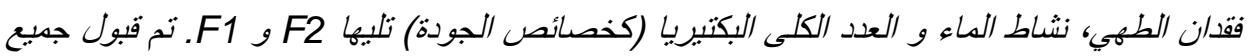

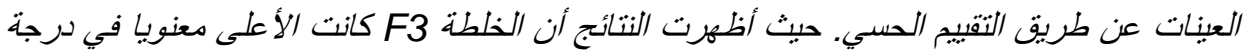

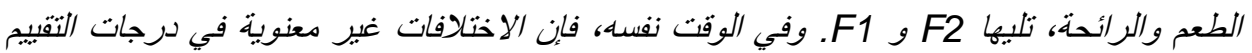

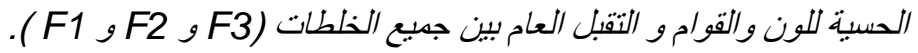

الكلمات المفتاحية: لحم الجمبري المجفف ـ الكفتة المجفهه -كفتة الجمبري المجفف 